\title{
OFFSHORING: WHY DO STORIES DIFFER?
}

\author{
WILHELM KOHLER
}

CESIFO WORKING PAPER NO. 2231

CATEGORY 7: TRADE POLICY

FEBRUARY 2008

\footnotetext{
An electronic version of the paper may be downloaded

- from the SSRN website: Www.SSRN.com

- from the RePEc website: $\quad$ www.RePEc.org

- from the CESifo website: $\quad$ www.CESifo-group.org/wp
} 


\title{
OFFSHORING: WHY DO STORIES DIFFER?
}

\begin{abstract}
This paper identifies critical modeling choices, as well as differences in the driving forces behind offshoring, that may explain differences in results. Offshoring of industry-specific tasks has wage and employment effects that are vastly different from those identified in Grossman \& Rossi-Hansberg (2006), depending on how the industries differ in their average and marginal skill-intensities, respectively. Structural adjustment may occur at the intensive margin and the extensive margin (offshoring), and it may occur in opposite directions or the same direction at both margins, again depending on how industries differ in terms of their average and marginal skill-intensity.
\end{abstract}

JEL Code: F11, F16.

\author{
Wilhelm Kohler \\ Eberhard Karls University Tübingen \\ Nauklerstrasse 47 \\ 72074 Tübingen \\ Germany \\ wilhelm.kohler@uni-tuebingen.de
}

January 2008

I wish to acknowledge financial support received from Fritz Thyssen Foundation under grant no Az. 10.06.1.111. Thanks are due to Christoph Roth for thoughtful and critical remarks on an earlier version of the paper. 


\section{Introduction}

It is now almost 20 years since Jones \& Kierzkowski (1990) have first pointed out the emergence of a new trend in globalization that was made possible mainly because of advances in the technology of transportation and communication: the fragmentation of production across borders. In the 1990s, this phenomenon became known as outsourcing. Krugman (1995) was the first to argue that an increased tendency towards outsourcing could be a partial explanation for the rising skill-premium in wages observed to a varying degree in many advanced industrial countries. Feenstra \& Hanson (1997) were the first to offer a theoretical model for this type of explanation, with the important property that outsourcing would lead to the same effect on the skill-premium in both, the "North" (where outsourcing takes place) and the "South" (the target country of such outsourcing activities). Subsequently, a sizable literature has developed, focusing either on the specific conditions that favor outsourcing, or on the effects that it has on the outsourcing country's wages, employment and welfare. In this process the terminology has undergone certain changes, whereby outsourcing relates to procurement via market-based transactions versus "in-house" operation of a given stage of the production process. What was originally called international fragmentation or outsourcing is now commonly referred to as offshoring, meaning that firms delocalize certain production-stages to other countries in order to arbitrage on international factor-cost differences. Obviously this can either happen through an "in-house" operation, or through cross-border outsourcing.

Empirical measurement of offshoring notoriously suffers from certain problems of precise definition and data limits, but it is probably fair to conclude from existing studies that the quantitative significance of offshoring is relatively low, at least below what would justify the enormous attention that offshoring has dawn in the policy debate; see for instance Bhagwati et al. (2004). More recently, this attention has even increased, due to evidence that the practice of offshoring is by no means restricted to production stages intensive in low-skilled-labor and requiring relatively little high-skilled labor. Several authors have been arguing that much of the additional offshoring to be expected for the future will probably affect high-skilled workers much more than was the case in the past, maybe even more than low-skilled labor; see for instance Markusen (2006) and Blinder (2006).

From existing empirical studies, it is relatively easy to quote both, numbers that por- 
tray offshoring as a relatively minor phenomenon, and numbers suggesting that it marks a major shift in international trade. In a recent study, the OECD calculates a countryspecific index of offshoring, based on the share of imported non-energy intermediate inputs in various industries' total use of non-energy intermediates. On this account, the smaller European countries, like Belgium, Austria and Denmark, reveal a high level of offshoring, with index-values for 2000 in the vicinity of 0.7. ${ }^{1}$ Large countries like Japan and the US, however, appear much less prone to offshoring, with index-values well below 0.2. In all countries considered, the offshoring-index for 2000 is larger than for 1995, although growth rates rarely exceed 20 percent. Interestingly, the index values are largest for manufacturing intermediates in manufacturing industries, about 7 to 8 times the values for service intermediates and service industries. However, such indices have very limited information content. They certainly cover much more than would be considered as offshoring in theoretical analyses, or in the policy debate. Moreover, inter-country comparisons make little sense, since they do not control for gravity-type effects.

Some authors have looked directly at jobs reported to have fallen victim to offshoring, which seems much closer to the notion of offshoring, although there's bound to be some blur. Relating the number of such job losses to aggregate job losses over the relevant period (early 2000s) and in the countries considered (mostly the US), offshoring seems like a minor nuisance: In three of the four studies reported in OECD (2007), offshoring was involved in no more than 1 percent of the job losses. ${ }^{2}$ The EU has investigated job losses in a detailed analysis of 3.475 cases of industrial restructuring that took place in various member countries between 2003 and 2006. Offshoring to countries outside the EU has turned out as an ingredient of restructuring in 10 percent of the cases, and responsible for about 8 percent of the announced job losses. This suggests a somewhat bigger importance, but the authors still conclude that the scale of offshoring is "smaller than might be expected". Interestingly, there is no evidence from this exercise that the phenomenon has gained importance during the years. But it is difficult to say what such numbers might tell us. May we conclude that all the discussion about offshoring is "much ado" about next to nothing? Or do these figures simply reflect an underutilized, but large

\footnotetext{
${ }^{1} \mathrm{An}$ index value of 0.7 means that on average a country's industries are estimated to rely on imports for 70 percent of their non-energy intermediate inputs; see OECD (2007, pp 61).

${ }^{2}$ A similar conclusion emerges from Belessiotis, Levin \& Veugelers (2007).
} 
potential?

A number of consultancies have ventured to estimate the jobs likely to be moved offshore. The numbers appear somewhat more impressive, between 1 and 9 percent of the estimated aggregate job losses, although still difficult to interpret without a clear benchmark. Taking a broader perspective, some others have even ventured to estimate the number of jobs that could potentially be moved offshore, mostly for the US. Expressing job losses as a percent of the relevant employment figure, offshoring now looks a more intimidating spectre, causing layoffs between 10 and 25 percent of employment. ${ }^{3}$

If there is substantial disagreement about the quantitative significance of the phenomenon itself, this is aggravated by ambiguous messages about its effects. From an economic policy perspective, three dimension seem important. One is welfare, the question of whether we may view offshoring as a phenomenon that enhances the gains from trade. The second is distribution, the main concern being its effect on domestic wages in the offshoring country. And finally, there is concern about displacement effects in industries where offshoring is observed. Economic theory suggests that the three dimensions are closely interrelated, but empirical studies have tended to focus on single aspects, mainly looking at either wage or employment effects. Unfortunately, however, the stories presented differ widely. ${ }^{4}$ In very broad terms, there are two reasons for this. One has to do with the ambiguity regarding measurement of offshoring itself; see the preceding paragraph. The second has to do with the lack of clear guidance from theory as to how, exactly, estimation equations should be specified. Both problems, particularly the second, are familiar from the literature on trade and wages.

There are two principal modeling approaches to offshoring. One is to follow traditional trade theory, using general equilibrium models. These models may in turn be Ricardian or Heckscher-Ohlin in nature, taking a long-run view on comparative advantage, or they may be more short-run in nature, assuming factor specificity as in the Ricardo-Viner model. ${ }^{5}$ The strengths of these models is their ability to address welfare and distribu-

\footnotetext{
${ }^{3}$ See OECD (2007, p.90). Blinder (2006) is particularly outspoken in identifying a large potential for offshoring, particularly in high-skilled-labor intensive tasks.

${ }^{4}$ A convenient survey is found in Belessiotis et al. (2006). See also Kohler (2007).

${ }^{5}$ This type of literature essentially goes back to Jones \& Kierzkowski (1990). Important contributions are Feenstra \& Hanson (1997), Jones (2000), Jones \& Kierzkowski (2001a,2001b),
} 
tional concerns, which also seem to dominate the policy debate. This approach views offshoring as a result of some exogenous change in the cost of cross-border linking of production stages (cost of transportation and/or communication across distance and jurisdictions), which allows for a finer exploitation of cross country differences in the factor cost of performing different tasks in production. Such costs will in general also relate to the organizational mode of doing things, such as arms-length transactions versus intrafirm transactions. However, in this first approach, these costs are typically treated as a 'black box'. In contrast, the second approach to analyzing offshoring is to open this box, thereby also shedding light on the nature of transactional problems that are responsible for whether firms chose one mode of sourcing over another, in addition to determining where to source their inputs or tasks of production. ${ }^{6}$ Typically, however, models in this tradition are somewhat short on factor price effects and distribution, which is arguably a dominating concern of the policy debate.

In this paper, the focus lies squarely on the first approach which places much emphasis on factor-cost considerations behind offshoring, and on general equilibrium repercussions, but which takes a very simple view on the transaction-costs of offshoring, and which largely remains silent about the particular organizational form in which offshoring might take place. The results derived obtain independently on the specific organizational form. The model proposed is inspired by the Heckscher-Ohlin model of comparative advantage and trade. The purpose of the analysis is to shed light on the three different issues that have been addressed in the empirical literature, and the differing stories that exist where it has sometimes been difficult to interpret the results obtained, largely for lack of a lucid theoretical exposition of the effects in question. The first issue relates to the so-called productivity effect of offshoring. The second relates to the wage (or more generally factor price) effects of offshoring. And the third relates to employment (or more generally reallocation) effects of offshoring. The model will show that offshoring does indeed incorporate something like a productivity effect. It drives the gains from

Deardorff (2001a,2001b,2005), Kohler (2003,2004b), and Grossman \& Rossi-Hansberg (2006), which are all inspired by the Heckscher-Ohlin model. Kohler $(2001,2004 \mathrm{~b})$ and Bhagwati et al. (2004) take a Ricardo-Viner perspective.

${ }^{6}$ Important contributions to this type of literature are McLaren (2000), Grossman \& Helpman (2002,2005) and Antras \& Helpman (2004). 
offshoring that many economists almost routinely emphasize when discussing the virtue of offshoring, alluding to the general principle of gains from trade. However, the model also suggests that (and explains why) empirical studies should have a hard time identifying such productivity effects. As to the factor price and employment effects, the model will reveal that the a-priori intuition that inspires much of the empirical work ex ante, and is usually invoked ex post in order to interpret the results obtained, is potentially misleading.

The paper is structured as follows. Section two presents a simple two-sector model where production takes place in a continuum of production stages, or tasks, each relying on high- and low-skilled labor, respectively, with a varying skill-intensity which is assumed to be given (Leontief-type technology). I describe the extensive margin of offshoring as an endogenous variable. Offshoring is driven by juxtaposing the factor cost-advantage of some foreign location where low-skilled labor is relatively cheap, and the extra cost of connecting production stages towards final goods production. I also introduce the concept of marginal skill intensity of an industry, marginal meaning at the extensive margin of offshoring, and the average skill intensity across the entire range of domestic tasks. Section three then turns to a general equilibrium analysis of a simple scenario which involves a reduction of the offshoring cost. Importantly, this is allowed to happen independently in both industries. I shall explore in some detail a key difference that arises between two different fundamental views of offshoring. One views offshoring as an input-related phenomenon, by definition applying to all industries at the same time, while the other views offshoring as a phenomenon which is idiosyncratic for each industry, and which always affects both types of labor within the industry. The former concept is used in the recent paper by Grossman \& Rossi-Hansberg (2006), whereas the latter has been used by Kohler (2003) and Kohler (2004b). It turns out that the wage effects of a reduction in the cost of offshoring are dramatically different for the two modes of offshoring. In section four, I explore a scenario where domestic industries respond to a change in final goods prices, given exogenously from world markets. Does an industry contract or expand simultaneously at the intensive margin (meaning contraction or expansion of all existing domestic tasks), and at the extensive margin (meaning an expansion or reduction in the measure of tasks performed domestically, as opposed to offshore)? I introduce a concept of skill-intensity-difference between industries that allows us to tell whether an industry moves in the same direction on both margins, or whether industries expand (contract) at the intensive margin, while contracting (expanding) at the extensive margin. Again, 
it will turn out that the two concepts of offshoring hold different messages. In section five I shall draw some conclusions, with special emphasis on implications for empirical modeling.

\section{A Simple Model}

Any model of offshoring requires to be explicit about the way in which a certain production process may be decomposed, or fragmented, such that various parts may take place at two different locations (countries) featuring different factor costs. Factor costs may be different in two countries either because they have different technologies, or because they have different factor prices. I focus on factor price differences as determinants of factor cost advantages, although I do allow for technology differences to play a role as well. As regards factor cost, I assume that there is a foreign economy with given wage rates for high-skilled labor and low-skilled labor, respectively, denoted by $\bar{w}_{h}$ and $\bar{w}_{l}$. I thus assume a two-factor setup with high-skilled and low-skilled labor as the only inputs. Labor endowments are considered as given exogenously for the larger part of my analysis. ${ }^{7}$

I also assume two final goods, where production is assumed to require a continuum of tasks, each requiring inputs of the two types of labor in a certain ratio, according to a Leontief-type production relationship. It will become evident that the model could be generalized to allow for factor substitution with relatively little effort, but since there are almost zero gains from doing so I stick to the Leontief-case. I use $a_{i h}(j)$ and $a_{i l}(j)$ to denote the fixed input coefficients "per unit" of task $j$ in production of good $i{ }^{8}$ The continuous variable $j \in[0,1]$ is used to index tasks, and $i=\{1,2\}$ is used to index the two goods, or industries. Moreover, $f_{i}(j)$ denotes the "amount" of task $j$ that is required per unit of

\footnotetext{
${ }^{7}$ The model is inspired by Dornbusch, Fischer \& Samuelson (1980), Dixit \& Grossman (1982), Feenstra \& Hanson (1997), and the recent contribution by Grossman \& Rossi-Hansberg (2006). See also Kohler (2004). The distinctive features of the model used here will be emphasized as I go along.

${ }^{8}$ Due to Grossman \& Roossi-Hansberg (2006), it has now become standard to talk of tasks, where earlier literature has referred to stages of production, or fragments. Likewise, it has become costumary to use offshoring to describe foreign (as opposed to domestic) sourcing of tasks, leaving the precise mode of sourcing indetermined (in-house or outsourcing).
} 
good $i$. Thus technology is also of the Leontief-type regarding the tasks, in addition to the types of labor used for each task. Essentially, $f_{i}(j)$ measures inverse task-productivities, or the "importance" of different tasks in production, across the continuum of tasks from $j=0$ to $j=1$. By appropriate scaling of output-units, I assume a unitary measure of tasks, i.e., $\int_{0}^{1} f_{i}(j) \mathrm{d} j=1$. Notice that this does not imply a uniform distribution of inverse task-productivities (or importance) across $j$. Using $w_{h}$ and $w_{l}$ to denote the domestic economy's wage rate for high- and low-skilled labor, respectively, the factor-cost per unit of good $i$, barring any possibility of offshoring, is

$$
c_{i}\left(w_{h}, w_{l}\right)=\int_{0}^{1} f_{i}(j)\left[a_{i h}(j) w_{h}+a_{i l}(j) w_{l}\right] \mathrm{d} j
$$

Suppose now that there is a technology of linking tasks across distance. More specifically, if the home economy produces good $i$ with some of the tasks performed in the other country, then the "amount" of task $j$ that needs to be performed by foreign labor, in order to secure availability of an equivalent to $f_{i}(j)$ domestic tasks, is $t_{i}(j) f_{i}(j)$, where $t_{i}(j)>1$ is allowed to vary across tasks, differently across industries. This employs the notion of iceberg-cost to offshoring, capturing all costs involved in "gluing" tasks across locations. ${ }^{9}$ We do not dwell on details here, other than the fact that these costs vary across tasks. We now define

$$
\gamma_{i}\left(w_{h}, w_{l}, j\right):=\left[a_{i h}(j) w_{h}+a_{i l}(j) w_{l}\right] /\left[a_{i h}(j) \bar{w}_{h}+a_{i l}(j) \bar{w}_{l}\right]
$$

as a measure of the factor cost of offshoring that derives from the factor intensity of tasks and the factor price difference between the domestic and the foreign economy. We know from multiple-good-versions of the Heckscher-Ohlin theory that ranking tasks in such a way that $a_{i h}(j) / a_{i l}(j)$ is weakly increasing in $j$ for both goods implies monotonicity of $\gamma_{i}(\cdot, j)$ in $j$. More specifically, for $w_{h} / w_{l}>\bar{w}_{h} / \bar{w}_{l}$ the factor-cost-advantage $\gamma_{i}(\cdot, j)$ is non-increasing in $j$, and vice versa for $w_{h} / w_{l}<\bar{w}_{h} / \bar{w}_{l} \cdot{ }^{10}$ For $w_{h} / w_{l}=\bar{w}_{h} / \bar{w}_{l}, \gamma_{i}$ does not depend on $j$. We denote this level of $\gamma_{i}$ level by $\bar{\gamma}_{i}$. If $\bar{\gamma}_{i}>1$, this indicates an acrossthe-board absolute cost advantage of the foreign economy. Without loss of generality we may normalize $\bar{\gamma}_{i}=1$.

\footnotetext{
${ }^{9}$ See Baldwin (2006b). Jones \& Kierzkowski (2005) call this the "extra cost of service link activities".

${ }^{10}$ See Jones (1956) and Dornbusch, Fischer \& Samuelson (1980).
} 
Cost-minimization requires that firms delocalize a task $j$, if $\left[a_{i h}(j) w_{h}+a_{i l}(j) w_{l}\right]>$ $\left[a_{i h}(j) \bar{w}_{h}+a_{i l}(j) \bar{w}_{l}\right] t_{i}(j)$, i.e., if $\gamma_{i}\left(w_{h}, w_{l}, j\right) / t_{i}(j)>1$. There is a unique cut-off point separating tasks where cost-minimization dictates delocalization, or offshoring, and tasks to be performed domestically, provided that $\gamma_{i}\left(w_{h}, w_{l}, j\right) / t_{i}(j)$ is strongly monotonic in $j$. A convenient assumption often made is that it strongly decreases in $j$. The usual interpretation is that $w_{h} / w_{l}>\bar{w}_{h} / \bar{w}_{l}$ and the cost of offshoring, $t_{i}(j)$, rises in $j$, or at least that $\gamma_{i}\left(w_{h}, w_{l}, j\right) / t_{i}(j)$ inherits the factor-cost-based monotonicity from $\gamma_{i}\left(w_{h}, w_{l}, j\right)$. However, this may seem questionable. It is not the skill-intensity of a task per se that makes it more or less "offshorable", but the degree to which it may be described in algorithmic terms, or the degree to which it requires face-to-face contact or complex communication. As argued by Blinder (2005,2007a,2007b) and others, it is by no means clear that ranking tasks in terms of "gluing-cost" replicates the ranking in terms of skillintensity. Unless stated otherwise, In what follows I assume that there is a rank-order of tasks such that $\gamma_{i}\left(w_{h}, w_{l}, j\right) / t_{i}(j)$ decreases monotonically in $j$, and that this rank order also implies that $a_{i h}(j) / a_{i l}(j)$ is rising in $j$.

I now denote the cost-minimizing cut-off value of $j$ that satisfies

$$
\gamma_{i}\left(w_{h}, w_{l}, j\right) / t_{i}(j)=1
$$

by $j_{i}^{*}\left(w_{h}, w_{l}\right){ }^{11}$ In Kohler $(2004 \mathrm{~b}, 2007)$ I have called this the extensive margin of offshoring. It obviously depends on domestic factor prices. The cut-off level $j_{i}^{*}$ satisfies the first-order-condition for the unit-cost with offshoring, i.e.,

$$
\begin{aligned}
\tilde{c}_{i}\left(w_{h}, w_{l}, j\right): & =\int_{0}^{j} t_{i}(k) f_{i}(k)\left[a_{i h}(k) \bar{w}_{h}+a_{i l}(k) \bar{w}_{l}\right] \mathrm{d} k \\
& +\int_{j}^{1} f_{i}(k)\left[a_{i h}(k) w_{h}+a_{i l}(k) w_{l}\right] \mathrm{d} k
\end{aligned}
$$

with respect to $j$. This first-order-condition simply requires $\gamma_{i}\left(w_{h}, w_{l}, j\right) / t_{i}(j)=1$, and the second-order-condition is satisfied from the aforementioned monotonicity. It is instructive to consider the partial equilibrium comparative statics of $j_{i}^{*}$, holding factor prices constant. Thus, consider the case where $t_{i}(j)=\beta_{i} z_{i}(j)$, and let there be an exogenous change $\Delta \beta_{i}<0$. For given domestic wages, this results in an increase in $j_{i}^{*}$

${ }^{11}$ This corresponds to the condition $\left(w / w^{*}\right) /[\beta t(I)]=1$ in Grossman \& Rossi-Hansberg (2006b). 
which we could derive from the differential of the first-order-condition on $j_{i}^{*}$. Intuitively, the flatter $\gamma_{i}\left(w_{h}, w_{l}, j\right) / t_{i}(j)$ with respect to $j$, the stronger the reaction of the extensive margin of offshoring. In turn, a relatively flat schedule may arise from a flat factor intensity ranking, meaning a relatively homogeneous set of tasks, and/or a flat $t_{i}(j)$-schedule. We might call such an industry relatively sensitive with respect to offshoring.

We may also explore offshoring effects of changes in factor prices. Any domestic wage change that increases costs at the marginal stage of production, $a_{i h}\left(j_{i}^{*}\right) \mathrm{d} w_{h}+a_{i l}\left(j_{i}^{*}\right) \mathrm{d} w_{l}>$ 0 , makes the domestic economy uncompetitive at the margin and leads firms to delocalize further stages until the condition $\gamma_{i}\left(w_{h}, w_{l}, j\right) / t_{i}(j)=1$ is reached. The opposite holds true for wage changes that satisfy $a_{i h}\left(j_{i}^{*}\right) \mathrm{d} w_{h}+a_{i l}\left(j_{i}^{*}\right) \mathrm{d} w_{l}<0$. Any factor price change that satisfies $a_{i h}\left(j_{i}^{*}\right) \mathrm{d} w_{h}+a_{i l}\left(j_{i}^{*}\right) \mathrm{d} w_{l}=0$ leaves the extensive margin of offshoring unaffected. This property will be important when we consider how offshoring behaves in the process of industrial restructuring.

The schedule $j_{i}^{*}\left(w_{h}, w_{l}\right)$ describes offshoring behavior of industry $i$, independently on the price of its output, because offshoring is purely a matter of cost-minimization. Given our assumptions, there is a lower bound of $w_{l} / w_{h}$ for which $j_{i}^{*}=0$, and an upper bound for $j_{i}^{*}=1$. Industries may obviously differ in their offshoring characteristics, and the schedule $j_{i}^{*}\left(w_{h}, w_{l}\right)$ is a convenient way of describing these characteristic. For the sake of a simpler notation, I have abstained from indicating that $j_{i}^{*}$ is also a function of foreign wage rates which we treat as parametric throughout this paper.

It will prove convenient to introduce the distinction between the marginal and the average domestic skill intensity of an industry. The marginal skill-intensity is denoted by $\alpha_{i}\left(w_{h}, w_{l}\right):=a_{i h}\left[j_{i}^{*}\left(w_{h}, w_{l}\right)\right] / a_{i l}\left[j_{i}^{*}\left(w_{h}, w_{l}\right)\right]$, while the average skill-intensity is denoted by $\tilde{\alpha}_{i}\left(w_{h}, w_{l}\right):=\tilde{a}_{i h}\left(w_{h}, w_{l}\right) / \tilde{a}_{i l}\left(w_{h}, w_{l}\right)$, whereby

$$
\tilde{a}_{i s}\left(w_{h}, w_{l}\right):=\int_{j_{i}^{*}\left(w_{h}, w_{l}\right)}^{1} a_{i s}(j) f_{i}(j) \mathrm{d} j \text { for } s=h, l
$$

The complementary definition of the average skill intensity of the delocalized part of production is denoted by $\bar{\alpha}_{i}\left(w_{h}, w_{l}\right):=\bar{a}_{i h}\left(w_{h}, w_{l}\right) / \bar{a}_{i l}\left(w_{h}, w_{l}\right)$, whereby

$$
\bar{a}_{i s}\left(w_{h}, w_{l}\right):=\int_{0}^{j_{i}^{*}\left(w_{h}, w_{l}\right)} a_{i s}(j) t_{i}(j) f_{i}(j) \mathrm{d} j \text { for } s=h, l
$$

Of course, the difference between the marginal and the average skill intensity vanishes 
as $j_{i}^{*}$ approaches 1 . Note that the coefficients $a_{i s}$ are constant by assumption, While $\bar{a}_{i s}$ depends on domestic wages through the first-order condition on $j_{i}^{*}$.

With these definitions, we may now move from the partial industry perspective to general equilibrium. We look at a small open economy facing given world prices $p_{1}$ and $p_{2}$ for the two goods. With offshoring, the zero-profit-conditions are

$$
p_{i}-\left[\bar{a}_{i h}\left(w_{h}, w_{l}\right) \bar{w}_{h}+\bar{a}_{i l}\left(w_{h}, w_{l}\right) \bar{w}_{l}\right] \leq \tilde{a}_{i h}\left(w_{h}, w_{l}\right) w_{h}+\tilde{a}_{i l}\left(w_{h}, w_{l}\right) w_{l} \quad \text { for } \quad i=1,2
$$

with equality if there is any remaining home production in industry $i$. In line with the theory of effective protection, we may call the left-hand side of (7) the effective price for the domestic value added in industry $i .{ }^{12}$ Denoting this effective price by $\pi_{i}\left(p_{i}, w_{h}, w_{l}\right)$, we arrive at conventional zero-profit-conditions of the following form:

$$
\pi_{i}\left(p_{i}, w_{h}, w_{l}\right) \leq \tilde{a}_{i h}\left(w_{h}, w_{l}\right) w_{h}+\tilde{a}_{i l}\left(w_{h}, w_{l}\right) w_{l} \quad \text { for } \quad i=1,2
$$

again with equality if industry $i$ is at least partly viable domestically, meaning $j_{i}^{*}\left(w_{h}, w_{l}\right)<$ 1. The key difference to the conventional zero-profit-condition is that instead of the price $p_{i}$ we now have an effective price, which depends on domestic wage rates. It also depends on the technology of offshoring, $t_{i}(j)$, which enters through the extensive margin $j_{i}^{*}$, as well as through the function $t_{i}(j)$ in the integral (6).

It must be re-emphasized that the condition governing the extensive margin of fragmentation is influenced by the given wage rates in the forgeign economy. In general equilibrium, these zero-profit-conditions must be satisfied simultaneously for all industries. In addition, equilibrium requires full employment

$$
\bar{a}_{1 s}\left(w_{h}, w_{l}\right) y_{1}+\bar{a}_{2 s}\left(w_{h}, w_{l}\right) y_{2}=L_{s} \quad \text { for } \quad s=h, l
$$

Equations (7) and (9) determine the two domestic wage rates as well as the "gross-size" of the two industries, $y_{1}$ and $y_{2}$. The offshoring-schedules $j_{i}^{*}\left(w_{h}, w_{l}\right)$ then determine the degree of delocalization in production of the two industries.

\footnotetext{
${ }^{12}$ I have introduced this concept in Kohler (2003); see also Kohler (2004b and 2007).
} 


\section{Gobalization: The Good of It}

I now proceed to comparative static analysis. First, I consider the oft-quoted story of a "more global village", which in the present modeling setup amounts to a reduction of $t_{i}(j)$. As Grossman \& Rossi-Hansberg (2006b) have emphasized, for this scenario to have interesting effects, one must assume offshoring to be present in the initial equilibrium. This generates infra-marginal effects. I assume that the cost of service link activities obey $t_{i}(j)=\beta_{i} z_{i}(j)$, and I assume $\hat{\beta}_{i}:=\Delta \beta_{i} / \beta_{i}<0$. Hence, globalization increases the ease with which offshoring may take place across the board for all tasks involved in any one industry. I call it the "good of globalization", since it involves a true cost-saving, a reduction in real offshoring-cost. In the next section, I will turn to a somewhat less benign form in which globalization presents itself, which is simply a fall in world-market prices of traded goods. However, I want to allow for $\hat{\beta}_{1} \neq \hat{\beta}_{2}$. This is a crucial point, much less innocuous than may appear at first sight. It has to do with a fundamental property of our offshoring technology, and a property which separates this model from Grossman \& Rossi-Hansberg (2006). It warrants a brief digression.

In this model, offshoring is an industry-specific phenomenon, relating to the idiosyncratic way in which the value added process of a certain industry may be sliced up, or fragmented, into different tasks. Each task, the smallest possible unit of the value added process, requires composite labor according to a Leontief-type technology. Accordingly, the "gluing-cost" for delocalized tasks are also an idiosyncratic element of an industry's technology. Any improvement in this glue (globalization scenario) is thus also an industry-specific element, but within the industry it affects all types of labor directly. Other industries may be affected indirectly through general equilibrium repercussions.

By way of contrast, Grossman \& Rossi-Hansberg (2006) define offshoring as an inputspecific phenomenon, whereby the term input directly relates to a certain type of labor. If globalization allows easier gluing of input-specific tasks performed at different locations, then this directly affects all industries using this input, but it does not directly affect other tasks. Indeed, they are not affected indirectly, as we shall see below.

These are two fundamentally different perceptions of what offshoring is all about. Both seem to have some merits empirically. The difference between them in terms of formal analysis is best illustrated in the present context if we make a further simplifying assumption. Let me thus assume that the input-coefficients for high-skilled and low-skilled 
labor are the same across tasks, i.e, $a_{i s}(j)=a_{i s}$ for $s=h, l$ and $i=1,2$. This assumption, also made by Grossman \& Rossi-Hansberg (2006), is enormously helpful analytically, since it allows us to substitute for foreign factor-cost, using the first-order-condition on the extensive margin $j_{i}^{*}$, which now reads as

$$
a_{i h} \bar{w}_{h}+a_{i l} \bar{w}_{l}=\frac{a_{i h} w_{h}+a_{i l} w_{l}}{\beta_{i} z_{i}\left(j_{i}^{*}\right)}
$$

Notice that we have now replaced $t_{i}(j)=\beta_{i} z_{i}(j)$. I still denote the endogenous margin of offshoring by the schedule $j_{i}^{*}\left(w_{h}, w_{l}\right)$, which depends parametrically on foreign wages $\bar{w}_{h}$ and $\bar{w}_{l}$. Replacing accordingly in (5) and (6), we obtain the following zero-profitconditions:

$$
\begin{aligned}
p_{i} & =\left(a_{i h} w_{h}+a_{i l} w_{l}\right) S_{i}\left[j_{i}^{*}\left(w_{h}, w_{l}\right)\right] \quad \text { for } \quad i=1,2 \\
\text { where } \quad S_{i}\left[j_{i}^{*}\left(w_{h}, w_{l}\right)\right] & :=\frac{1}{z_{i}\left(j_{i}^{*}\right)} \int_{0}^{j_{i}^{*}\left(w_{h}, w_{l}\right)} z_{i}(j) f_{i}(j) \mathrm{d} j+\int_{j_{i}^{*}\left(w_{h}, w_{l}\right)}^{1} f_{i}(j) \mathrm{d} j
\end{aligned}
$$

The schedule $S_{i}\left[j_{i}^{*}\left(w_{h}, w_{l}\right)\right]$ captures how changes in the technology of offshoring affect the total factor cost of industry $i$ through a change in the cost-minimizing extensive margin $j_{i}^{*}$. A number of things are worth emphasizing about this. ${ }^{13}$ Due to the second-ordercondition on $j_{i}^{*}$, we have $S_{i}<1$, which reflects the simple fact that offshoring leads to a net savings on factor cost. Moreover, note that the shift parameters $\beta_{i}$ have disappeared through substitution, which may seem counter-intuitive. However, they still play a role through determining the equilibrium margins of offshoring in the two industries, $j_{1}^{*}$ and $j_{2}^{*}$. It is obvious that $S_{i}^{\prime}<0$, and I use $\omega_{i}:=S_{i}^{\prime} j_{i}^{*} / S_{i}<0$ to denote the elasticity of the "offshoring-savings-factor" $S_{i}$ with respect to $j_{i}^{*}$. And finally, for $j_{i}^{*}=0$ we have $S_{i}=1$, due to the assumed unitary measure of $f_{i}(j)$.

According to (10), for constant foreign wage rates, the comparative statics of the extensive margin satisfies

$$
\hat{\jmath}_{i}^{*}=\frac{1}{\zeta_{i}}\left(\theta_{i h} \hat{w}_{h}+\theta_{i l} \hat{w}_{l}-\hat{\beta}_{i}\right)
$$

where $\zeta_{i}:=z_{i}^{\prime} j_{i} / z_{i}>0$ denotes the elasticity of the "gluing-cost" function $z_{i}(j)$, which now drives all movements at the extensive margin, due to the assumption of otherwise

\footnotetext{
${ }^{13}$ This discussion relies on Grossman \& Rossi-Hansberg (2006). For a comparison of results see below.
} 
homogeneous tasks. Note that this elasticity is evaluated at the initial equilibrium value of $j_{i}^{*}$. I use $\theta_{i s}$ to denote the cost-share of factor $s$, as usual. Assuming a small country facing constant final goods prices $p$, the zero profit conditions 11) imply

$$
\theta_{i h} \hat{w}_{h}+\theta_{i l} \hat{w}_{l}+\omega_{i} \hat{\jmath}_{i}^{*}=0
$$

Combining these two equations, our globalization scenario now emerges as

$$
\frac{\omega_{i}}{\zeta_{i}+\omega_{i}} \hat{\beta}_{i}=\left(\theta_{i h} \hat{w}_{h}+\theta_{i l} \hat{w}_{l}\right) \quad \text { for } \quad i=1,2
$$

At first sight, the comparative statics may seem ambiguous, since $\zeta_{i}>0$ and $\omega_{i}<0$ are of opposite signs. However, these two elasticities are intimately related to each other, and it is relatively straightforward from plain intuition that $\zeta_{i}>\left|\omega_{i}\right|$. The elasticity $\zeta_{i}$ measures the extent to which expanding the scope of offshoring increases the marginal offshoringcost $z_{i}(j)$. The elasticity $\omega_{i}$ measures the extent to which doing so increases the entire factor cost savings from offshoring, relative to all-home-production, measured through the "offshoring-savings-factor" $S_{i}<1$. Both elasticities are evaluated for equilibrium values where the first-order-condition on $j_{i}^{*}$ is satisfied. This condition requires that the marginal effects would just offset each other, but since $S_{i}$ includes the infra-marginal savings effects which are smaller (due to the assumption that $\zeta_{i}^{\prime}(j)>0$ ), the marginal effect measured by $\zeta_{i}$ must dominate the effect on $S_{i}$ in absolute value: $\zeta_{i}>\left|\omega_{i}\right|$, whence $\omega_{i} /\left(\zeta_{i}+\omega_{i}\right)<0$. It should be noticed that the left hand side of (15) is the percentage increase of the effective price, as defined in (8), that is brought about by a $\hat{\beta}_{i}$-percent reduction in the offshoring cost. Thus, the productivity effects may equivalently be expressed as an increase in the effective price $^{14}$

Equation (15) is intuitive, both directly and also from the notion of an effective price change. If firms in a certain industry already engage in offshoring, i.e., if $j_{i}^{*}>0$, any across the board reduction in "gluing-costs" through $\hat{\beta}_{i}<0$ acts just like an increase in the price of the good, given that $\omega_{i} /\left(\zeta_{i}+\omega_{i}\right)<0$, as demonstrated before. ${ }^{15}$ An alternative way to describe the same effect is to say that offshoring makes domestic factors used in an industry uniformly more productive. The strength of the effect depends on how far the industry

\footnotetext{
${ }^{14}$ I have emphasized this perspective already in Kohler $(2003,2004)$, but without offering an explicit solution for $\hat{\pi}_{i}$.

${ }^{15}$ See Kohler (2003) where I have first pointed out that offshoring may be seen in this way.
} 
has already gone in terms of the scope of offshoring. This is because of the inframarginal effect of making all those tasks cheaper to obtain that have already been sourced abroad, prior to the fall in $\beta_{i}$. If $f_{i}(j)$ is uniform, this effect is measured through the margin $j_{i}^{*}$ alone. If $f_{i}(j)$ varies across $j$, meaning that some tasks are inherently more important for production than others, then this effect is the larger, the more important the tasks that have been delocalized to start with. Moreover, the strength of the effect depends on the steepness of the $z_{i}(j)$-schedule. Taken together, the strength of this equivalent-priceincrease for a given size of the shock is given through the term $\omega_{i} /\left(\zeta_{i}+\omega_{i}\right)<0$.

As regards the general equilibrium effects, we may now invoke Stolper-Samuelson logic to pin down the wage effects of offshoring, provided that the economy is and remains diversified. The diversification condition matters because any change in $j_{i}^{*}$ also affects the full employment conditions, since less domestic labor is now used to generate outputs $y_{1}$ and $y_{2}$. Under our assumption of constant input coefficients across all tasks, both types of labor are affected symmetrically. Offshoring just acts like a sector-biased technological change, which may be equivalently be treated as an effective change in the supply of both types of labor. In our case, this happens in a disproportional way, but as long as this does not push the economy outside its cone of diversification, the wage effects are determined in the familiar way from the zero-profit-conditions alone.

With a view on the fundamental distinction between two different concepts of offshoring introduced above, it should now be instructive to compare this expression with the corresponding result in Grossman \& Rossi-Hansberg (2006). To have a meaningful comparison, we need to look at the more general case where they allow for trade in tasks for both low- and high-skilled labor. For this case, their zero-profit-conditions read as (in terms of our notation)

$$
p_{i}=a_{i h} w_{h} S_{h}\left[j_{h}^{*}\left(w_{h}\right)\right]+a_{i l} w_{l} S_{l}\left[j_{l}^{*}\left(w_{l}\right)\right] \quad \text { for } \quad i=1,2
$$

where $S_{s}$ is defined by analogy to (12), the only difference being that they assume $f_{s}(j)$ to be uniform with measure 1 , now relating to input $s=\{h, l\}$, and not to industry $i=\{1,2\}$, as in our model. The comparative statics on $j_{s}^{*}$ in their case simply require $\hat{\jmath}_{s}^{*}=\left(\hat{w}_{s}-\hat{\beta}_{s}\right) / \zeta_{s}$, where $\zeta_{s}$ is defined by analogy to $\zeta_{i}$ above. For constant goods prices $p_{i}$ the two equations (16) uniquely determine equilibrium domestic factor costs for each of the two factors, high- and low-skilled labor, $w_{h} S_{h}\left[j_{h}^{*}\left(w_{h}\right)\right]$ and $w_{l} S_{l}\left[j_{l}^{*}\left(w_{l}\right)\right]$, respectively. Hence, comparative statics must obey $\hat{w}_{s}=\hat{S}_{s}$, independently for both $s=h$ and $s=l$. 
Offshoring of the two types of tasks takes place with no connection whatsoever between these two phenomena. ${ }^{16}$ This is a stark separation property for input-specific offshoring which, obviously, does not hold for industry-specific offshoring.

What are the conclusions to be drawn from this analysis? A first point to be made in view of the counter-intuitive results that I have emphasized in Kohler (2003) and Kohler (2007) is that these are ruled out here because of the continuity imposed on offshoring through assuming a continuum of tasks. The above analysis looks at small changes where all "pathologies" behind counter-intuitive results are ruled out.

However, with a view on the empirical literature it must still be emphasized that some of the direct intuition often invoked is misleading. As has often been pointed out by trade economists in the debate about "trade and wages", in open economies wages are determined by prices through the zero-profit-conditions, more than by quantities - say quantities traded. In the present context a similar point obtains for offshoring. More specifically, we may have an industry where in a given period (sample) a lot of action takes place in terms of going offshore, and we may be confident that it is all a story about $\hat{\beta}_{i}<0$. Yet, if this happens at a "young age" of offshoring, with $j_{i}^{*}$ close to zero at the outset, then we should not be surprised to find small effects on wages. In other words, when we estimate the role of offshoring through an empirical implementation of zero-profit-conditions like (15) above, we should also attempt to observe, by whatever proxi might be available, the terms $\omega_{i} /\left(\zeta_{i}+\omega_{i}\right)$ across industries.

And it does matter from the above whether offshoring is of one or the other type, tasks that are idiosyncratic for industries, or tasks that are idiosyncratic to certain types of labor. For the latter type of offshoring, we do have a somewhat counter-intuitive result that offshoring of tasks that strictly require low-skilled labor raises the domestic wage for low-skilled labor. The same applies, independently, for offshoring of strictly highskill-labor-tasks. As with other results that appear counter-intuitive at first sight, closer inspection reveals Stolper-Samuelson logic at work. If the effective cost of domestic lowskilled labor falls, because of cheaper availability of low-skilled-labor-tasks sourced abroad, this benefits the low-skilled-labor-intensive industry more than the other industry, and the only way to restore zero-profits is through an offsetting rise in the domestic wage for

\footnotetext{
${ }^{16}$ See section 4 of Grossman \& Rossi-Hansberg (2006b) for more details.
} 
low-skilled labor. Again, the same logic applies independently for high-skilled-labor-tasks. And in either case the effect would be much smaller at "early stages" of offshoring than for later stages where $j_{i}^{*}$ is already "large".

A further point relates to welfare and real wages. With strictly input-specific offshoring, we would always observe a rise in real wages for both types of labor. Offshoring is a Pareto-improving event. The same does not hold true for industry-specific offshoring where the Stolper-Samuelson logic applies in a more familiar way. For this type of offshoring to be a Pareto-improvement, it would have to be sufficiently symmetric in terms of $\hat{\beta}_{i} \omega_{i} /\left(\zeta_{i}+\omega_{i}\right)$ being not too different in absolute magnitude across industries.

And finally, as regards the productivity effect that has also been the object of empirical analysis, ${ }^{17}$ in this model all productivity-equivalent gains are absorbed by factor price changes. It is thus difficult to imagine how productivity gains would show up in an empirical analysis. Of course, there is much more to data than this model can identify. In particular, productivity effects at the industry level may be due to firm heterogeneity as in Melitz (2003), which is ruled out here altogether. However, there is a certain similarity between the new literature on heterogeneity-driven productivity effects that work through firm selection. As I have suggested in Kohler (2007), we may re-interpret our $t_{i}(j)$ schedule as incorporating a varying degree of Ricardian comparative advantage, driven by productivity-differences, across different tasks, in addition to the offshoring-cost emphasized above. In this case, enhanced globalization also elicits selection of, and enhanced concentration on, tasks where domestic firms have a larger degree of comparative advantage. Indeed, we may even view our continuum of tasks as also involving a continuum of different firms. The question then remains how to define productivity in such a way that we may detect a productivity effect of offshoring, not in addition to factor price effects, but as a different, but equivalent, way of observing the same phenomenon - realizing that the factor price effects are essentially mandated from the productivity effects of offshoring.

\footnotetext{
${ }^{17}$ See for instance Mann (2003), Mann \& Kirkegaard (2006), Amiti \& Wei (2005) and Görg \& Girma (2004).
} 


\section{Globalization: A Less Benign Interpretation}

In the preceeding section, the globalization scenario was essentially good news since it has involved easier access to cheap things from abroad. In this section, I want to take a somewhat less benign perspective on globalization. Thus, suppose that due to enhanced world supply of good 1, its price falls on world markets. Domestic firms in industry 1 will perceive this as an increase in competitive pressure, and they will have to adjust. For the economy as a whole, this requires an adjustment in wage rates, as well as factor reallocation across industries which may be costly, and may involve temporary unemployment. From a general equilibrium perspective, in a two-goods-model it only makes sense to look at the relative price. Without loss of generality, I shall therefore look at a fall in the relative price of good 1 by normalizing $p_{2}=1$. I do not want to take a stance as to whether this constitutes a terms-of-trade improvement or a terms-of-trade deterioration, although one can easily portray the scenario in that way by assuming an appropriate demand and trade pattern. However, my story is not a terms-of-trade story, but a story of structural adjustment of a country's production, dictated by some exogenous change in world market prices. Of course, the story might just as well be told as one of a price increase, in which case it might look more benign. But globalization here is still less benign than in the previous section, simply because it now is a two-sided coin, as each relative price change is, whereas before it was one-sided in that there was an improvement in technology.

The issue that I want to address is how long-run adjustment of domestic production evolves in the face of secular changes of comparative advantage, brought about by an exogenous change in relative prices of traded goods. Of course, adjustment in quantities and prices are not independent. Both sides adjust simultaneously, and in interdependence. Indeed, if wages are perfectly flexible, then the wage adjustment might seem more important for policy than the associated adjustment in quantities in terms of reallocation and industrial restructuring. But there are important reasons why the quantity side is important to look at in its own right. First, if the reallocation effects associated with adjustment under flexible prices are large, then the unemployment effect that would arise in case of wage rigidities is also large. Looking at the quantity side of adjustment is, thus, a first and rough way to gauge the potential unemployment problem that may arise from a certain scenario if wages are rigid. The second reason has to do with adjustment costs, 
which are often assumed away. Short of explicitly modeling such costs, the magnitude of adjustment in quantities that arise from a given scenario may give a first and rough indication of the likely costs of adjustments.

An issue that is not usually addressed, but which may be important, is whether the long-run decline of a certain industry in terms of employment goes hand in hand with a gradual reduction also in production depth. One might be inclined to assume that it does, but the subsequent analysis reveals that the opposite is also possible, whereby an ever smaller number of people employed in an industry carry out an ever larger set of tasks, covering an ever larger range of production stages. In a similar vein, if a country acquires comparative advantage in some industry, will this necessarily happen in the form of a gradual increase not only in employment, but also in the number of production stages carried out domestically? Or might the industry increase in size (employment) through specialization on an ever smaller subset of production stages? Arguably, adjustment costs may be quite different in the two forms of restructuring. I shall not, however, model such costs explicitly in this paper.

With Leontief-type technology, goods price changes normally do not entail any reallocation at all. Under flexible prices, all adjustment takes place in factor price space, until - in the extreme case - one of the two factors has a zero shadow value and production adjusts in a discrete way towards complete specialization. To allow for a more interesting story of quantity adjustment, we need to return to the more general model where there is a systematic variation of skill-intensity across the continuum of tasks in both industries considered. In this case, offshoring makes the skill-intensity variable. But even if tasks are homogeneous in terms of skill-intensity, the conclusion from the above analysis would be that offshoring introduces an element of continuity into adjustment through the rising cost-schedule $t_{i}(j)$. Moreover, the previous analysis seems to suggest that an exogenous price increase (reduction) should have the effect of a reduction (increase) in offshoring. This follows from the fact that offshoring is the equivalent, in terms of the zero-profit-conditions, of a price increase. Hence, a price reduction may partly be undone through offshoring. However, in this section I want to show a special feature of adjustment that arises in the more appealing case where tasks are heterogeneous in terms of their skill-intensity.

It will prove useful for the subsequent analysis to introduce the following definitions, relying on the notions of average and marginal skill-intensity introduced in (5) above. I 
shall call industry 1 strongly more skill-intensive than industry 2 , if it features both, a higher average and a higher marginal skill intensity than industry 2, for given external margins of offshoring, $j_{1}^{*}$ and $j_{2}^{*}$. I call industry 1 weakly more skill intensive, if at the given levels of $j_{i}^{*}$ its average skill intensity is higher, but its marginal skill intensity is lower than in industry 2's average skill-intensity. And finally, industry 1 is called globally more skill intensive than industry 2 , if its marginal skill intensities over the entire range of $j_{i} \in[0,1]$ span a skill-intensity-cone which is disjoint from, and more skill-intensive, than the corresponding cone for industry 2. It turns out that with this definition, important qualitative results may be obtained without having to work out a full closed-form-solution of the comparative statics. Moreover, the difference between our two forms of offshoring are also relatively easy to establish. I first look at the case of industry-specific offshoring with heterogeneous tasks, followed by a brief treatment of the same scenario for the alternative concept of offshoring proposed by Grossman \& Rossi-Hansberg (2006).

It is important a the outset to note that our scenario is an exogenous reduction in the relative price of a good which is relatively skill-intensive in the average sense. In the conventional scenario we would expect a decline in employment of both types of labor in this industry, and a reallocation towards industry 2. This happens through the equilibrium wage adjustments which make high-skilled labor relatively cheaper, thus making both industries more skill-intensive. And full employment then requires a contraction of the more skill-intensive of the two industries. As a first step, let us thus look at notional wage adjustments that would maintain the zero-profit conditions in the face of $\mathrm{d} p_{1}<0$ without any change in the margin of offshoring. Assuming diversification, using (7) this type of wage adjustment is described by

$$
\begin{aligned}
\mathrm{d} p_{1} & =\tilde{a}_{1 h}\left(w_{h}, w_{l}\right) \mathrm{d} w_{h}+\tilde{a}_{1 l}\left(w_{h}, w_{l}\right) \mathrm{d} w_{l}<0 \\
0 & =\tilde{a}_{2 h}\left(w_{h}, w_{l}\right) \mathrm{d} w_{h}+\tilde{a}_{2 l}\left(w_{h}, w_{l}\right) \mathrm{d} w_{l}
\end{aligned}
$$

where the second equation explicitly states that the price of good two has been normalized to $p_{2}=1$. Note that by construction of my argument the factor cost for delocalized tasks on the left-hand side of (7) remain unchanged. We might call it the incipient wage adjustment. Now suppose that industry 1 is weakly more skill-intensive than industry 2 at the initial levels of offshoring $j_{i}^{*}$ and domestic wage rates, $w_{h}$ and $w_{l}$, respectively. This means that $\tilde{a}_{1 h}(\cdot) / \tilde{a}_{1 l}(\cdot)>\tilde{a}_{2 h}(\cdot) / \tilde{a}_{2 l}(\cdot)>a_{1 h}\left[j_{i}^{*}\left(w_{h}, w_{l}\right)\right] / a_{1 l}\left[j_{i}^{*}\left(w_{h}, w_{l}\right)\right]$, where the average skill-intensities are defined as in (5) above, and where $a_{1 s}\left[j_{i}^{*}\left(w_{h}, w_{l}\right)\right]$ denotes the 
$s$-type labor input-coefficient at the initial margin $j_{i}^{*}$, with $s=h, l$. Remember that $j_{i}^{*}$ satisfies the first-order-condition of cost-minimization through localization of tasks (10).

Obviously, under these skill-intensity assumptions, the wage changes from (17) feature a fall in $w_{h}$ and a rise in $w_{l}$, such that minimum-cost of industry 2 remains constant. Since the marginal task of industry 1 features a lower skill-intensity than industry 2 does on the average of its tasks, this implies that the factor cost of that task must rise. The reason is that a lower skill-intensity makes it less well positioned to gain from a relative reduction of the high-skilled wage rate. From (10) it then follows that these notional wage adjustments are no equilibrium reactions, since they violate the first-order-condition. More specifically, the rise in $w_{l}$ and fall in $w_{h}$ are such that the domestic economy loses its competitive edge on the marginal task $j_{i}^{*}$ of the skill-intensive industry 1, and cost-minimization requires that further tasks are delocalized offshore. The same holds true for the less skillintensive industry 2 , since by definition each industry's average skill-intensity is larger than its marginal skill-intensity. In other words, equilibrium adjustment in this case requires enhanced offshoring in both industries. Both industries thus become more skillintensive in the process of adjustment, although for "small changes" industry 1 remains the more skill-intensive of the two on the average of all tasks performed domestically. The equilibrium wage adjustment is in line with the Stolper-Samuelson logic, although different from that described in equations (17) above. ${ }^{18}$

The opposite holds true for industry 1, if it is strongly more skill-intensive than industry 2 , and a fortiori if it is globally more skill-intensive. In this case we observe a partial reversal of offshoring in industry 1 , since notional the wage adjustment according to (17) now implies that industry 1 actually gains a competitive edge on the marginal task. The opposite still holds true for industry 2 (as in the previous case), by definition of the average skill-intensity in (5). Hence, equilibrium adjustment must now involve less offshoring in industry 1, and more offshoring in industry 2. As a result, industry 1 becomes less skill-intensive, while industry 2 becomes more skill-intensive. The factor-intensity effect of offshoring thus reduces the skill-intensity difference between the two industries. This, in turn, implies that the Stolper-Samuelson logic, although still in force, implies a somewhat mitigated adjustment, compared to a case where offshoring is ruled out. As regards overall

\footnotetext{
${ }^{18}$ In Kohler (2004b), I present a similar analysis using a dual version of a somewhat simpler model where offshoring takes place only in one of the two industries.
} 
resource allocation, we lose the Rybczynski-type logic which normally implies contraction of industry 1 and expansion of industry 2 . The reason is that, the factor intensities of the two industries now move in opposite directions.

To draw a somewhat more general conclusion, it is important to realize the specific nature of the scenario considered. In our model, industry 1 might be called a comparative advantage industry, because it is relatively skill-intensive on the average of tasks and the home economy has relatively cheap high-skilled labor. This industry faces increased competitive pressure from a fall in the price of good 1. Somewhat paradoxically, the conventional type of adjustment obtains, if the industry is the less skill-intensive at the margin of offshoring than the other industry on is average. The intuition is that in this case the incipient rise in $w_{l}$ and fall in $w_{h}$ harms the industry also at its offshoring margin. If the industry is skill-intensive also at this margin, then the incipient wage effects lead to opposite movements in the skill-intensities of the two industries that mitigate the StolperSamuelson logic and potentially negate the Rybczynski-logic for factor reallocation.

Suppose that we have an exogenous relative price increase of industry 1, rather than a price reduction. Then the wage effects described by (17), with $\mathrm{d} p_{1}>0$, now go the other way, with a rise in $w_{h}$ and a fall in $w_{l}$. Reiterating the logic of the preceding argument, we would conclude that if industry 1 is weakly more skill-intensive its reaction would involve a partial reversal of offshoring. The reason is that it is relatively less skill-intensive in terms of the task at the relevant margin of offshoring, hence it is less affected by the changes $\mathrm{d} w_{h}>0$ and $\mathrm{d} w_{l}<0$ from (17). The same holds true, by definition of average skill intensities as in (5), for industry 2. From Rybczynski-type logic, industry 1 expands, while industry 2 contracts. If industry 1 is strongly more skill-intensive, then these same wage adjustments would imply that industry 1 loses its competitive edge at the initial margin of offshoring, and would therefore react by delocalizing more tasks offshore, while the opposite holds true for industry 2. Thus, adjustment implies an increase in factorintensity differences. The result is that the Stolper-Samuelson logic gets reinforced, and the Rybczynski-type logic is lost, potentially at least.

The conclusion to be drawn from this analysis for empirical work is that it makes relatively little sense to search for an unambiguous relationship between changes in the extent of an industry's level of offshoring, and changes in employment or more generally its level of activity. Everything depends on the type of exogenous shock that drives the data. Offshoring and employment, together with the wage effects, are all jointly endogenous, 
and ignoring this endogeneity in the estimation process, without bothering about the type of exogenous shock that generates the variation observed in the data, leads to potentially meaningless results.

The preceding analysis indicates a rich pattern of possible industrial restructuring in a country that faces a change in world prices for traded final goods, and whose firms engage in offshoring to countries where low-skilled labor is relatively cheap. The underlying assumption was that offshoring is an industry-specific phenomenon involving heterogeneous tasks. A somewhat simpler pattern of restructuring obtains, if offshoring is specific to inputs as proposed by Grossman \& Rossi-Hansberg (2006). Without going into details, I want to show in what follows why things are different and simpler in this alternative world. Changes in relative wages within the domestic economy, a key channel of the effects considered in this section, are entirely irrelevant for offshoring. Industrial restructuring caused by price changes does involve changes in offshoring, however, also in the GR-model. From (16), the domestic factor cost for tasks, $w_{h} S_{h}\left[j_{h}^{*}\left(w_{h}\right)\right]$ and $w_{l} S_{l}\left[j_{l}^{*}\left(w_{l}\right)\right]$ responds in the familiar way to goods price changes. With given foreign wage rates and given offshoring margins $j_{i}^{*}$, this disturbs the offshoring condition. By necessity, it does so in both sectors, and the offshoring margins of the two industries will always move in the same direction.

More specifically, from (16), the factor cost changes following a change in $p_{1}$ must satisfy the familiar magnification relationship of the Stolper-Samuelson theorem. I.e., under the assumption that industry 1 is relatively skill intensive, $\hat{p}_{1}<0$ must be associated with a fall in $w_{h} S_{h}\left[j_{h}^{*}\left(w_{h}\right)\right]$, and a rise in $w_{l} S_{l}\left[j_{l}^{*}\left(w_{l}\right)\right]$. Now, since the extensive margins $j_{s}^{*}$ are increasing in the respective wage rates, and $S_{s}^{\prime}<0$, and since we now assume a constant offshoring-cost and a constant foreign wage rate, a fall in $w_{h}$ will be associated with a rise in $S_{h}$, i.e., a partial reversal offshoring. This is intuitive, since a lower domestic wage for high-skilled labor makes the domestic economy competitive at the initial margin of offshoring. Whether or not this is an equilibrium adjustment depends on whether it is true that $\hat{w}_{h}+\omega_{h} \hat{\jmath}_{h}^{*}<0$, with $\hat{w}_{h}<0$. From the first order condition of offshoring which in this case states that $\bar{w}_{h}=w_{h} /\left[\beta_{h} z_{h}\left(j_{h}^{*}\right)\right]$, we have $\hat{\jmath}_{h}^{*}=\hat{w}_{h} / \zeta_{h}$. Hence the condition is satisfied, if $\hat{w}_{h}\left(1+\omega_{h} / \zeta_{h}\right)<0$, which in turn implies $\omega_{h} / \zeta_{h}>-1$, which is equivalent to $\zeta_{h}>-\omega_{h}$, or $\zeta_{h}>\left|\omega_{h}\right|$. Now, we know that $\zeta_{h}>0$ and $\omega_{h}<0$, and in section 3 above we have also shown that the equivalent of condition $\zeta_{h}>\left|\omega_{h}\right|$ is satisfied for the industryspecific notion of offshoring. By analogy, it is also satisfied in the present context. From 
all of this it then follows that, for an equilibrium adjustment to $\hat{p}_{1}<0$, we do have $\hat{w}_{h}<0$ with $\hat{S}_{h}>0$, and conversely for low-skilled labor where $\hat{w}_{l}>0$ and $\hat{S}_{l}<0$. We may thus conclude that the Stolper-Samuelson theorem remains valid in qualitative terms for the Grossman-Rossi-Hansberg world of offshoring. ${ }^{19}$

For the reallocation effects it is now important to realize that the full employment conditions are given by

$$
\begin{aligned}
a_{1 h} S_{h}\left[j_{h}^{*}\left(w_{h}\right)\right] y_{1}+a_{2 h} S_{h}\left[j_{h}^{*}\left(w_{h}\right)\right] y_{2} & =L_{h} \\
a_{1 l} S_{l}\left[j_{l}^{*}\left(w_{l}\right)\right] y_{1}+a_{i 2} S_{l}\left[j_{l}^{*}\left(w_{l}\right)\right] y_{2} & =L_{l}
\end{aligned}
$$

From the previous paragraph we know that $S_{h}$ is rising, while $S_{l}$ is falling, in identical ways for both industries. Denoting the familiar employment shares by $\lambda_{i s}:=$ $a_{i s} S_{s}\left[j_{s}^{*}\left(w_{s}\right)\right] y_{i} / L_{s}$, we may write the relative changes as

$$
\begin{aligned}
\lambda_{1 h} \hat{y}_{1}+\left(1-\lambda_{1 h}\right) \hat{y}_{2} & =-\hat{S}_{h}<0 \\
\lambda_{1 l} \hat{y}_{1}+\left(1-\lambda_{1 l}\right) \hat{y}_{2} & =-\hat{S}_{l}>0
\end{aligned}
$$

From this, we may directly conclude that output levels respond as in the Rybczynski-type magnification effect: $\hat{y}_{1}<-\hat{S}_{h}<0<-\hat{S}_{l}<\hat{y}_{2}$. This is as expected. However, it relates to final output levels, not to employment of labor in the two industries. As emphasized above, overall employment in industry 1 falls, as perhaps expected, if both industries become more skill-intensive in the process of adjustment, with the skill-intensity measured as $a_{i h} S_{h}\left[j_{h}^{*}\left(w_{h}\right)\right] /\left(a_{i l} S_{l}\left[j_{l}^{*}\left(w_{l}\right)\right]\right)$. Since $\hat{S}_{h}<0<-\hat{S}_{l}$, i.e., since both industries conduct more offshoring of low-skilled tasks and a partial offshoring-reversal of high-skilled tasks, this condition is unambiguously satisfied, and the employment reaction is in line with the traditional model and plain intuition. More competitive pressure on the final output side of industry 1 leads to a contraction, not only of gross output, but also of domestic employment of both factors in that industry. The reverse happens in industry 2. Notice that we are experiencing a certain degree of gradualism in resource reallocation where without offshoring we would have no reaction up to a point, with a subsequent discrete jump to complete specialization.

\footnotetext{
${ }^{19}$ See also Baldwin \& Robert-Nicaud (2007).
} 


\section{Conclusion}

Stories of offshoring differ for two non-trivial reasons. First, the underlying view of the offshoring phenomenon may differ, and secondly, the scenario looked at in theoretical models, or the exogenous changes behind the data used in empirical work, may differ. If these differences are made explicit, then the different stories should not cause confusion. However, in empirical work at least, this is often not the case. And theoretical models usually subscribe, more or less arbitrarily, to a specific, single notion of offshoring. Moreover, they mostly look at scenarios where offshoring arises (sometimes from a case without offshoring to start with) due to an exogenous reduction of offshoring-costs. Offshoring as an ingredient to adjustment of other types of shocks has received little attention. The empirical literature very often investigates the effects of offshoring on variables like wages and employment which are jointly endogenous with offshoring itself. If two variables are jointly endogenous, their co-movement depends on the type of exogenous shock that drives this movement. Unless the researcher is explicit about this, results are difficult to interpret, and one should not be too surprised that the stories reported differ.

In this paper, I have identified two different types of offshoring that are both amenable to general equilibrium analysis featuring several types of labor and may, thus, be compared in a rigorous way for the same type of scenario, focusing on distribution and factor allocation. Moreover, I have looked at two different scenarios to exemplify that the comovement of offshoring on the one hand, and wages and employment on the other heavily depends on the type of underlying shock.

Offshoring may be related to tasks that are specific to certain types of labor. All types of labor may be subject to offshoring, but the tasks of low-skilled labor may be delocalized independently from the tasks performed by high-skilled labor. This is the "new paradigm" of trade proposed recently by Grossman \& Rossi-Hansberg (2006). Alternatively, offshoring may be seen as an industry-specific phenomenon where the smallest unit of production that may be delocalized still involves bundles of many (or all) types of labor. It is then impossible to delocalize inputs of low-skilled labor independently of high-skilled labor. This type of offshoring has been looked at in earlier literature, but the two types have not been analyzed and compared in a unified framework.

I have analyzed these two phenomena in a unified way, relying on Grossman \& RossiHansberg (2006), focusing on factor cost savings of delocalization. But in addition to 
their scenario of a lower offshoring-cost, I have also looked at a case where offshoring is part of an industrial adjustment caused by a change in prices for tradable final goods, given exogenously from world markets. Among the results obtained, offshoring of lowskilled tasks always raises the wage for low-skilled labor, as emphasized by Grossman \& Rossi-Hansberg (2006), independently on factor intensity relationship between industries concerned. However, for the other type of offshoring factor intensity rankings do play a role, whereby a key distinction arises between the marginal and the average skill-intensity of an industry.

More interesting differences arise if one looks at the employment and factor price effects of a change in final goods prices. More specifically, if offshoring involves heterogeneous tasks involving bundles of both types of labor, then contraction or expansion of an industry caused by such price changes may take place in the same direction at both the extensive and intensive margin of adjustment. But, depending on the skill intensity difference between the industries concerned, contraction of total employment in an industry may go hand in hand with expansion at the extensive margin, meaning a partial reversal of offshoring. Indeed, adjustment no longer needs to be in line with the familiar Rybczynskitype magnification effect. However, adjustment takes more mainstream forms if offshoring is of the other type where tasks relate to single types of labor.

For empirical work, my analysis suggests that the specification of estimation equations for both, wage and employment effects, and the specific estimation technique chosen, should be sensitive with respect to the fact that offshoring, as well as wages and employment, are all jointly endogenous. Moreover, the empirical approach should allow for a distinction between the two types of offshoring. For the industry-specific form of offshoring, the specific ways in which industry-characteristics determine the wage and employment effects identified in the present analysis should be, and can be, taken into account in the empirical specification. 


\section{References}

[1] Antràs, Pol and Elhanan Helpman (2004), Global Sourcing, Journal of Political Economy $112,552-580$.

[2] Amiti, Mary and Shang-Jin Wei (2005a), Fear of Service Outsourcing: Is It Justified? Economic Policy 20, 307-347.

[3] Amiti, Mary and Shang-Jin Wei (2005b), Service Offshoring, Productivity, and Employment: Evidence from the United States, IMF Working Paper 5/238.

[4] Baldwin, Richard (2006b), Globalization: the great unbundling(s), prepared for the Finnish Prime Minister's Office, Economic Council of Finland, (in context of EU Presidency 2006).

[5] Baldwin, Richard and Nicoud, Frederic R. (2008), Trade and Growth with Heterogenous Firms,Journal of International Economics 74(1), 21-34 (January 2008).

[6] Belessiotis, T., M. Levin and R. Veugelers (2007), EU competitiveness and industrial location, European Commission, Bureau of European Policy Advisers, Luxembourg: European Communities.

[7] Bhagwati, J., Panagariya, A. Sirinivasan, T.N. (2004), The Muddles over Outsourcing. Journal of International Economics, vol. 14, 209-221.

[8] Blinder, A.S. (2005), Fear of Offshoring, Princeton University, CEPS Working Paper No. 119, December 2005.

[9] Blinder, A.S. (2006), Offshoring: The Next Industrial Revolution, Foreign Affairs March/april 2006.

[10] Blinder, A.S. (2007a), How Many U.S. Jobs Might Be Offshorable?, Princeton Univerisity, CEPS working paper no. 142, March 2007.

[11] Blinder, A.S. (2007b), Offshoring: Big Deal or Business as Usual?, Princeton University, CEPS working paper no. 149, June 2007.

[12] Dixit A. K. and Grossman, G. M. (1982). Trade and protection with multistage production. Review of Economic Studies, vol. 49, (October), 583-94. 
[13] Deardorff, Alan V. (2001a), Fragmentation in Simple Trade Models, North American Journal of Economics and Finance 12, 121-137.

[14] Deardorff, Alan V. (2001b), Fragmentation across cones, in: Sven W. Arndt and Henryk Kierzkowski (eds.), Fragmentation: New Production Patterns in the World Economy, Oxford: Oxford University Press.

[15] Deardorff, Alan V. (2005), A trade theorist's take on skilled-labor outsourcing, International Review of Economics and Finance 14, 259-271.

[16] Dornbusch, Rudiger, Fischer Stanley, and Samuelson Paul A. (1980), HeckscherOhlin Trade Theory with a Continium of Goods. Quarterly Journal of Economics, 95, 203-224.

[17] Feenstra, Robert C. and Gordon H. Hanson (1997), Foreign direct investment and relative wages: evidence from Mexico's Maquiladoras, Journal of International Economics 42, 371-93.

[18] Görg, Holger and Sourafel Girma (2004), Outsourcing, Foreign Ownership and Productivity: Evidence from UK Establishment Level Data, Review of International Economics 12, 817-832.

[19] Grossman, G. M. and Helpman, E. (2002). Integration versus outsourcing in industry equilibrium. Quarterly Journal Economics, vol. 1117, 85-120.

[20] Grossman, Gene M. and Elhanan Helpman (2005), Outsourcing in a Global Economy, Review of Economic Studies 72, 135-159.

[21] Grossman, Gene M. and Esteban Rossi-Hansberg (2006a), The Rise of Offshoring: It's not Wine for Cloth Anymore, Presented at the Federal Reserve Bank of Kansas City Economic Symposium "The New Economic Geography: Effects and Policy Implications", Jackson Hole, Wyoming, August 24-26, 2006.

[22] Grossman, Gene M. and Esteban Rossi-Hansberg (2006b), Trading Tasks: A Simple Theory of Offshoring, Mimeo, Princeton, N.J.: Princeton University.

[23] Jones, R. W. (1956). Factor proportions and the Heckscher-Ohlin theorem. Review of Economic Studies, vol. 24, (January), 1-10. 
[24] Jones, Ronald W. (2000), Globalization and the Theory of Input Trade, Cambridge, Mass.: MIT Press.

[25] Jones, Ronald W. and Henryk Kierzkowski (1990), The role of services in production and international trade: a theoretical framework, in: Ronald W. Jones and Anne O. Krueger (eds.), The Political Economy of International Trade, Oxford: Basil Blackwell.

[26] Jones, R. W. and H. Kierzkowski (2001a), A Framework for Fragmentation, in Arndt, S. W. and H. Kierzkowski (eds.), Fragmentation: New Production Patterns in the World Economy, Oxford University Press, Oxford.

[27] Jones, R.W., and Kierkowski, H. (2001b). Globalization and the consequences of international fragmentation. In Calvo, G., M. Obstfield and R. Dornbusch (eds.), Money, Capital Mobility, and Trade, Essays in Honor of Robert A. Mundell, Cambridge, MA: MIT-Press.

[28] Jones, R.W., and Kierzkowski, H. (2005), International fragmentation and the new economic geography. North American Journal of Economics and Finance, vol. 16, $1-10$.

[29] Kohler, Wilhelm (2001), A specific-factors view on outsourcing, North American Journal of Economics and Finance 12, 31-53.

[30] Kohler, Wilhelm (2003), The Distributional Effects of International Fragmentation, German Economic Review 4, 89-120.

[31] Kohler, Wilhelm (2004a), Aspects of International Fragmentation, Review of International Economics 12, 793-816.

[32] Kohler, Wilhelm (2004b), International Outsourcing and Factor Prices with Multistage Production, Economic Journal 114, C166-C185.

[33] Kohler, W. (2007). The Bazaar Effect, Unbundling of Comparative Advantage, and Migration, in Wolfgang Franz, Hans J. Ramser u. Manfred Stadler (eds.), Dynamik internationaler Märkte, Tübingen: Mohr-Siebeck, 2007.

[34] Krugman, P. (1995). Growing world trade: Causes and consequences. Brookings Papers on Economic Activity, I, 327-377. 
[35] McLaren, J. (2000), 'Globalisation' and Vertical Structure, American Economic Review, 90, 1239-1254.

[36] Mann, C.L. (2003), Globalization of IT services and white collar jobs: The next wave of productivity growth, International Economics Policy Briefs, Institute for International Economis, Washington D.C.

[37] Mann, C.L. and J.F. Kirkegaard (2006), Accelerating the Globalization of America: The Role of Information Technology, Washington D.C.: Institute for International Economics.

[38] Markusen, J.R. (2006). Modeling the Offshoring of White-Collar Services: from comparative advantage to the new theories of trade and FDI, in Brainard S.Lael and Susan Collins (eds.), Brookings Trade Forum 2005: Offshoring White-Collar Work, Washington: the Brookings Institution, 2006, 1-34.

[39] Melitz, Marc J. (2003), The Impact of Trade on Intra-Industry Reallocations and Aggregate Industry Productivity, Econometrica, Vol. 71, NO. 6 (November, 2003), 1695-1725.

[40] OECD (2007), Offshoring and Employment: Trends and Impacts, OECD, Paris. 


\section{CESifo Working Paper Series}

for full list see www.cesifo-group.org/wp

(address: Poschingerstr. 5, 81679 Munich, Germany, office@cesifo.de)

2168 Erkki Koskela and Jan König, Strategic Outsourcing, Profit Sharing and Equilibrium Unemployment, December 2007

2169 Egil Matsen and Øystein Thøgersen, Habit Formation, Strategic Extremism and Debt Policy, December 2007

2170 Torben M. Andersen and Allan Sørensen, Product Market Integration and Income Taxation: Distortions and Gains from Trade, December 2007

2171 J. Atsu Amegashie, American Idol: Should it be a Singing Contest or a Popularity Contest?, December 2007

2172 Patricia Apps and Ray Rees, Household Models: An Historical Perspective, December 2007

2173 Ben Greiner, Axel Ockenfels and Peter Werner, The Dynamic Interplay of Inequality and Trust - An Experimental Study, December 2007

2174 Michael Melvin and Magali Valero, The Dark Side of International Cross-Listing: Effects on Rival Firms at Home, December 2007

2175 Gebhard Flaig and Horst Rottmann, Labour Market Institutions and the Employment Intensity of Output Growth. An International Comparison, December 2007

2176 Alexander Chudik and M. Hashem Pesaran, Infinite Dimensional VARs and Factor Models, December 2007

2177 Christoph Moser and Axel Dreher, Do Markets Care about Central Bank Governor Changes? Evidence from Emerging Markets, December 2007

2178 Alessandra Sgobbi and Carlo Carraro, A Stochastic Multiple Players Multi-Issues Bargaining Model for the Piave River Basin, December 2007

2179 Christa Hainz, Creditor Passivity: The Effects of Bank Competition and Institutions on the Strategic Use of Bankruptcy Filings, December 2007

2180 Emilia Del Bono, Andrea Weber and Rudolf Winter-Ebmer, Clash of Career and Family: Fertility Decisions after Job Displacement, January 2008

2181 Harald Badinger and Peter Egger, Intra- and Inter-Industry Productivity Spillovers in OECD Manufacturing: A Spatial Econometric Perspective, January 2008

2182 María del Carmen Boado-Penas, Salvador Valdés-Prieto and Carlos Vidal-Meliá, the Actuarial Balance Sheet for Pay-As-You-Go Finance: Solvency Indicators for Spain and Sweden, January 2008 
2183 Assar Lindbeck, Economic-Social Interaction in China, January 2008

2184 Pierre Dubois, Bruno Jullien and Thierry Magnac, Formal and Informal Risk Sharing in LDCs: Theory and Empirical Evidence, January 2008

2185 Roel M. W. J. Beetsma, Ward E. Romp and Siert J. Vos, Intergenerational Risk Sharing, Pensions and Endogenous Labor Supply in General Equilibrium, January 2008

2186 Lans Bovenberg and Coen Teulings, Rhineland Exit?, January 2008

2187 Wolfgang Leininger and Axel Ockenfels, The Penalty-Duel and Institutional Design: Is there a Neeskens-Effect?, January 2008

2188 Sándor Csengődi and Dieter M. Urban, Foreign Takeovers and Wage Dispersion in Hungary, January 2008

2189 Joerg Baten and Andreas Böhm, Trends of Children's Height and Parental Unemployment: A Large-Scale Anthropometric Study on Eastern Germany, 1994 2006, January 2008

2190 Chris van Klaveren, Bernard van Praag and Henriette Maassen van den Brink, A Public Good Version of the Collective Household Model: An Empirical Approach with an Application to British Household Data, January 2008

2191 Harry Garretsen and Jolanda Peeters, FDI and the Relevance of Spatial Linkages: Do third Country Effects Matter for Dutch FDI?, January 2008

2192 Jan Bouckaert, Hans Degryse and Theon van Dijk, Price Discrimination Bans on Dominant Firms, January 2008

2193 M. Hashem Pesaran, L. Vanessa Smith and Takashi Yamagata, Panel Unit Root Tests in the Presence of a Multifactor Error Structure, January 2008

2194 Tomer Blumkin, Bradley J. Ruffle and Yosef Ganun, Are Income and Consumption Taxes ever really Equivalent? Evidence from a Real-Effort Experiment with Real Goods, January 2008

2195 Mika Widgrén, The Impact of Council's Internal Decision-Making Rules on the Future EU, January 2008

2196 Antonis Adam, Margarita Katsimi and Thomas Moutos, Inequality and the Import Demand Function, January 2008

2197 Helmut Seitz, Democratic Participation and the Size of Regions: An Empirical Study Using Data on German Counties, January 2008

2198 Theresa Fahrenberger and Hans Gersbach, Minority Voting and Long-term Decisions, January 2008 
2199 Chiara Dalle Nogare and Roberto Ricciuti, Term Limits: Do they really Affect Fiscal Policy Choices?, January 2008

2200 Andreas Bühn and Friedrich Schneider, MIMIC Models, Cointegration and Error Correction: An Application to the French Shadow Economy, January 2008

2201 Seppo Kari, Hanna Karikallio and Jukka Pirttilä, Anticipating Tax Change: Evidence from the Finnish Corporate Income Tax Reform of 2005, January 2008

2202 Walter Krämer and André Güttler, On Comparing the Accuracy of Default Predictions in the Rating Industry, January 2008

2203 Syed M. Ahsan and Panagiotis Tsigaris, The Efficiency Loss of Capital Income Taxation under Imperfect Loss Offset Provisions, January 2008

2204 P. Mohnen, F. C. Palm, S. Schim van der Loeff and A. Tiwari, Financial Constraints and other Obstacles: Are they a Threat to Innovation Activity?, January 2008

2205 Sascha O. Becker and Mathias Hoffmann, Equity Fund Ownership and the CrossRegional Diversification of Household Risk, January 2008

2206 Pedro R. D. Bom and Jenny E. Ligthart, How Productive is Public Capital? A MetaAnalysis, January 2008

2207 Martin Werding, Ageing and Productivity Growth: Are there Macro-level Cohort Effects of Human Capital?, January 2008

2208 Frederick van der Ploeg and Steven Poelhekke, Globalization and the Rise of MegaCities in the Developing World, February 2008

2209 Sara Biancini, Regulating National Firms in a Common Market, February 2008

2210 Jin Cao and Gerhard Illing, Liquidity Shortages and Monetary Policy, February 2008

2211 Mathias Kifmann, The Design of Pension Pay Out Options when the Health Status during Retirement is Uncertain, February 2008

2212 Laszlo Goerke, Tax Overpayments, Tax Evasion, and Book-Tax Differences, February 2008

2213 Jun-ichi Itaya and Heinrich W. Ursprung, Price and Death, February 2008

2214 Valentina Bosetti, Carlo Carraro and Emanuele Massetti, Banking Permits: Economic Efficiency and Distributional Effects, February 2008

2215 Assar Lindbeck, Mårten Palme and Mats Persson, Social Interaction and Sickness Absence, February 2008

2216 Gary E. Bolton and Axel Ockenfels, The Limits of Trust in Economic Transactions Investigations of Perfect Reputation Systems, February 2008 
2217 Hartmut Egger and Peter Egger, The Trade and Welfare Effects of Mergers in Space, February 2008

2218 Dorothee Crayen and Joerg Baten, Global Trends in Numeracy 1820-1949 and its Implications for Long-Run Growth, February 2008

2219 Stephane Dees, M. Hashem Pesaran, L. Vanessa Smith and Ron P. Smith, Identification of New Keynesian Phillips Curves from a Global Perspective, February 2008

2220 Jerome L. Stein, A Tale of Two Debt Crises: A Stochastic Optimal Control Analysis, February 2008

2221 Michael Melvin, Lukas Menkhoff and Maik Schmeling, Automating Exchange Rate Target Zones: Intervention via an Electronic Limit Order Book, February 2008

2222 Raymond Riezman and Ping Wang, Preference Bias and Outsourcing to Market: A Steady-State Analysis, February 2008

2223 Lars-Erik Borge and Jørn Rattsø, Young and Old Competing for Public Welfare Services, February 2008

2224 Jose Apesteguia, Steffen Huck, Jörg Oechssler and Simon Weidenholzer, Imitation and the Evolution of Walrasian Behavior: Theoretically Fragile but Behaviorally Robust, February 2008

2225 Walter Krämer, Long Memory with Markov-Switching GARCH, February 2008

2226 António Afonso and Christophe Rault, What do we really Know about Fiscal Sustainability in the EU? A Panel Data Diagnostic, February 2008

2227 Sergey M. Kadochnikov and Igor M. Drapkin, Market Structure, Technological Gap and Vertical Linkage Effects from Foreign Direct Investment, February 2008

2228 Guglielmo Maria Caporale, Davide Ciferri and Alessandro Girardi, Fiscal Shocks and Real Exchange Rate Dynamics: Some Evidence for Latin America, February 2008

2229 Scott Alan Carson, Geography and Insolation in $19^{\text {th }}$ Century US African-American and White Statures, February 2008

2230 Wolfgang Buchholz and Jan Schumacher, Discounting and Welfare Analysis Over Time: Choosing the $\eta$, February 2008

2231 M. Hashem Pesaran, Christoph Schleicher and Paolo Zaffaroni, Model Averaging in Risk Management with an Application to Futures Markets, February 2008

2232 Wilhelm Kohler, Offshoring: Why Do Stories Differ?, February 2008 